\title{
Modern technologies of a mineral material surface improvement for transport construction
}

\author{
Larisa Svatovskaya ${ }^{1, *}$, Vladislav Britov ${ }^{2}$, and Ivan Drobychev ${ }^{1}$ \\ ${ }^{1}$ Emperor Alexander I St.-Petersburg State Transport University (PGUPS), Moskovsky pr. 9, St.- \\ Petersburg, 190031, Russia \\ ${ }^{2}$ St.-Petersburg State Institute of Technology (Technical University), Moskovsky pr. 26, St.- \\ Petersburg, 190031, Russia
}

\begin{abstract}
The paper deals with technologies of a mineral material surface improvement for transport construction. Mineral surface is important because of its hardness, durability and other properties. Besides, it is necessary to protect it from aggressive environment. The purpose of the article is to introduce a few techniques of silica sol use in order to change mineral surface properties. The absorption, irrigation and watering processes were applied as the techniques. Both silica sol and its mixes with solutions contained $\mathrm{Ca}(\mathrm{II})$ ions were used as the substances. The experimental methods were carried out during the study. The experiment results have shown that hardness of the mineral material and foam concrete surface was increased up to $60 \%$ and the level of the soil strengthening was more than $0,5 \mathrm{MPa}$. It means that if silica sol and solutions containing $\mathrm{Ca}$ (II) ions are used a soil strength is increased more than $40-50 \%$. The results of the study are particularly useful for construction of motorways in order to extend their service life.
\end{abstract}

\section{Introduction}

The main idea of the paper is to improve properties of a mineral surface using silica sol as a substance for absorption, irrigation, watering and other techniques to obtain layers on a concrete surface through penetration silica sol with $\mathrm{Ca}(\mathrm{II})$ ions into pores and capillaries.

Nowadays in transport construction it is possible to distinguish at least two important problems which are concerned with a mineral stone surface. They are technical properties during operation and geoecoprotective properties for lithosphere preservation. Hardness and other properties of a mineral stone surface can be observed as technical ones. Among geoecoprotective properties penetrability is of great importance [1-5]. In any case, for improvement both of technical properties and geoecoprotective ones a mineral stone surface must be strengthened by means of some substances that can impart strength to a surface even without penetration.

Silica sol contained $\mathrm{Ca}$ (II) ions was used for new technologies of the mineral surface improvement. In the Table 1 silica sol properties as the base for new technologies are shown [1-5].

\footnotetext{
* Corresponding author: lbsvatovskaya@yandex.ru
} 
Table 1. Properties of silica sol complex.

\begin{tabular}{|l|l|}
\hline \multicolumn{1}{|c|}{ Property } & \multicolumn{1}{|c|}{ Property improvement } \\
\hline 1. $\begin{array}{l}\text { sol } \rightarrow \text { gel, sol conversion into silica gel } \\
\text { and calcium silicate hydrates gel }\end{array}$ & $\begin{array}{l}\text { glue ability and binding capability of the } \\
\text { dispersion }\end{array}$ \\
\hline $\begin{array}{l}\text { 2. reactions of the mineral material with } \\
\text { Ca(II) ions }\end{array}$ & hardness of the surface \\
\hline 3. complex of the conversion and reactions & strengthening of the soil geosystem \\
\hline
\end{tabular}

Taking into consideration thermodynamic calculations presented in the Table 2, one can see that the reactions between surface active agents and silica sol complex are allowed, the data from the Table 3 having been used for the calculations of thermodynamic parameters.

Table 2. Reactions of silica sol on the mineral stone surface.

\begin{tabular}{|c|c|c|}
\hline Reactions on the mineral stone surface & $\mathrm{pH}$ & $\begin{array}{l}\Delta \mathbf{G}^{\circ}{ }_{298}, \\
\mathrm{KJ} / \mathrm{mol}\end{array}$ \\
\hline 1. $\mathrm{CaSO}_{4} 2 \mathrm{H}_{2} \mathrm{O}+2\left(\mathrm{SiO}_{2} \mathrm{H}_{2} \mathrm{O}\right)+2 \mathrm{OH}+\mathrm{Ca}^{2+}=\mathrm{CaO} 2 \mathrm{SiO}_{2} 2 \mathrm{H}_{2} \mathrm{O}+\mathrm{CaSO}_{4}+3 \mathrm{H}_{2} \mathrm{O}$ & $>7$ & -248 \\
\hline 2. $\mathrm{Ca}(\mathrm{OH})_{2}+2\left(\mathrm{SiO}_{2} \mathrm{H}_{2} \mathrm{O}\right)=\mathrm{CaO} 2 \mathrm{SiO}_{2} 2 \mathrm{H}_{2} \mathrm{O}+\mathrm{H}_{2} \mathrm{O}$ & $>7$ & $-168,4$ \\
\hline 3. $2 \mathrm{Ca}(\mathrm{OH})_{2}+\mathrm{SiO}_{2} \mathrm{H}_{2} \mathrm{O}=2 \mathrm{CaO} \mathrm{SiO}_{2} 1,17 \mathrm{H}_{2} \mathrm{O}+1,83 \mathrm{H}_{2} \mathrm{O}$ & $>7$ & $-95,32$ \\
\hline 4. $2 \mathrm{Ca}(\mathrm{OH})_{2} \mathrm{SiO}_{2} 1,17 \mathrm{H}_{2} \mathrm{O}+2\left(\mathrm{SiO}_{2} \mathrm{H}_{2} \mathrm{O}\right)=2 \mathrm{CaO} 3 \mathrm{SiO}_{2} 2,5 \mathrm{H}_{2} \mathrm{O}+0,67 \mathrm{H}_{2} \mathrm{O}$ & $>7$ & $-740,8$ \\
\hline 5. $\mathrm{Ca}^{2+}+2\left(\mathrm{SiO}_{2} \mathrm{H}_{2} \mathrm{O}\right)+2 \mathrm{OH}=\mathrm{CaO} 2 \mathrm{SiO}_{2} 2 \mathrm{H}_{2} \mathrm{O}+\mathrm{H}_{2} \mathrm{O}$ & $>7$ & $-201,6$ \\
\hline 6. $6 \mathrm{Ca}^{2+}+3\left(2 \mathrm{SiO}_{2} 3 \mathrm{H}_{2} \mathrm{O}\right)+12 \mathrm{OH}=6 \mathrm{CaO} 6 \mathrm{SiO}_{2} \mathrm{H}_{2} \mathrm{O}+14 \mathrm{H}_{2} \mathrm{O}$ & $>7$ & $-287,9$ \\
\hline
\end{tabular}

It should be noted that other substances like ones given in the Table 2 can be used.

Table 3. Parameters of the substances' $\Delta \mathrm{G}^{\circ}{ }_{298}$.

\begin{tabular}{|l|c|}
\hline \multicolumn{1}{|c|}{ Substance } & $\Delta \mathbf{G}^{\mathbf{\circ}} \mathbf{2 9 8}, \mathbf{K J} / \mathbf{m o l}$ \\
\hline $\mathrm{CaO} 2 \mathrm{SiO}_{2} 2 \mathrm{H}_{2} \mathrm{O}$ & $-2869,1$ \\
\hline $\mathrm{CaSO}_{4} 0,2 \mathrm{H}_{2} \mathrm{O}$ & $-1794,01$ \\
\hline $\mathrm{CaSO} 4$ & -1319 \\
\hline $\mathrm{Ca}(\mathrm{OH})_{2}$ & $-895,89$ \\
\hline $2 \mathrm{CaO} \mathrm{SiO}_{2} 1,17 \mathrm{H}_{2} \mathrm{O}$ & $-2478,3$ \\
\hline $\mathrm{SiO}_{2} \mathrm{H}_{2} \mathrm{O}$ & $-1073,6$ \\
\hline $\mathrm{OH}^{-}$ & $-157,1$ \\
\hline $\mathrm{CaSO}$ & -1319 \\
\hline $\mathrm{Ca}(\mathrm{II})$ & $-552,5$ \\
\hline $\mathrm{H}_{2} \mathrm{O}$ & -237 \\
\hline $2 \mathrm{SiO}_{2} 3 \mathrm{H}_{2} \mathrm{O}$ & $-2426,6$ \\
\hline $6 \mathrm{CaO}_{6 \mathrm{SiO}_{2} \mathrm{H}_{2} \mathrm{O}}$ & $-9444,29$ \\
\hline
\end{tabular}

The Table 4 demonstrates the techniques of silica sol action on a transport construction geosystem. It is worth mentioning that any surface strengthening is named safe technology in this article.

Table 4. Safe technologies of a mineral geosystem strengthening by means of silica sol complex in transport construction.

\begin{tabular}{|l|l|l|l|l|}
\hline $\begin{array}{c}\text { Mineral geosystem } \\
\text { as the base for a } \\
\text { surface } \\
\text { preservation }\end{array}$ & $\begin{array}{c}\text { Construction } \\
\text { geosystem }\end{array}$ & $\begin{array}{l}\text { The aim of silica } \\
\text { sol complex use }\end{array}$ & $\begin{array}{c}\text { Techniques of } \\
\text { silica sol } \\
\text { complex use }\end{array}$ & $\begin{array}{l}\text { Details of } \\
\text { the use }\end{array}$ \\
\hline $\begin{array}{l}\text { 1. calcium } \\
\text { sulphate, } \\
\mathrm{CaSO}_{4} 2 \mathrm{H}_{2} \mathrm{O}\end{array}$ & $\begin{array}{l}\text { - articles } \\
\text { - structures }\end{array}$ & $\begin{array}{l}\text { - strengthening } \\
\text { of a surface } \\
\text { lithosphere } \\
\text { protection from } \\
\text { pollutants } \\
\text { absorbed by an }\end{array}$ & $\begin{array}{l}\text { - absorption } \\
\text { - irrigation } \\
\text { - watering }\end{array}$ & $\begin{array}{l}\text { silica sol } \\
\text { can be } \\
\text { used } \\
\text { several } \\
\text { times }\end{array}$ \\
\hline
\end{tabular}




\begin{tabular}{|c|c|c|c|c|}
\hline & & $\begin{array}{l}\text { artificial stone } \\
\text { - protection from } \\
\text { the } \\
\text { environment } \\
\text { impact }\end{array}$ & & \\
\hline $\begin{array}{l}2 . \text { calcium silicate } \\
\text { hydrates, } \\
\text { yCaO nSiO } x_{2} \mathrm{H}_{2} \mathrm{O} \\
\text { calcium } \\
\text { aluminate hydrates } \\
\text { and other binding } \\
\text { systems }\end{array}$ & $\begin{array}{l}\text { - concrete } \\
\text { articles } \\
\text { - structures }\end{array}$ & $\begin{array}{l}\text { - strengthening } \\
\text { of a surface } \\
\text { - lithosphere } \\
\text { protection from } \\
\text { pollutants } \\
\text { absorbed by an } \\
\text { artificial stone } \\
\text { - protection from } \\
\text { the } \\
\text { environment } \\
\text { impact }\end{array}$ & $\begin{array}{l}\text { - } \text { absorption } \\
\text { - } \text { irrigation } \\
\text { - watering }\end{array}$ & $\begin{array}{ll}\begin{array}{l}\text { silica sol } \\
\text { can be }\end{array} \\
\text { used } \\
\text { several } \\
\text { times }\end{array}$ \\
\hline $\begin{array}{lr}\text { 3. soils } & \text { and } \\
\text { structures } & \text { saturated } \\
\text { with } & \text { mineral } \\
\text { dispersions } & \text { (sand } \\
\text { and } & \text { slag } \\
\text { dispersions) } & \end{array}$ & $\begin{array}{l}\text { - mass } \\
\text { dispersed } \\
\text { materials }\end{array}$ & $\begin{array}{l}\text { - } \text { strengthening } \\
\text { - } \text { antidusting }\end{array}$ & $\begin{array}{l}\text { - } \text { irrigation } \\
\text { - } \text { watering } \\
\text { - } \quad \text { spraying }\end{array}$ & $\begin{array}{l}\text { silica sol } \\
\text { can be } \\
\text { used } \\
\text { several } \\
\text { times }\end{array}$ \\
\hline
\end{tabular}

\section{Methods}

1,5-30\% silica sol with $\mathrm{Ca}(\mathrm{II})$ ions was used as a substance for absorption, irrigation and watering, particle sizes having been nearly $10 \mathrm{~nm}, \mathrm{pH}-10$. Three techniques were applied in the research, namely: absorption - for articles and structures, irrigation and watering for structures and soils. When absorption technology was applied after 28 days of hardening the articles and structures were sunk into 1,5-30\% silica sol for 1 day in order to saturate them to a full level. Both heavy concrete articles and foam concrete ones had the same concrete grade B30 with an average density $400-600 \mathrm{~kg} / \mathrm{m}^{3}$. The material consumption for foam concrete is illustrated in the Table 5, mechanical properties of the concrete having been tested according to the Russian standards.

Table 5. The material consumption for foam concrete having a density $400-600 \mathrm{~kg} / \mathrm{m}^{3}$.

\begin{tabular}{|c|c|c|c|c|c|c|c|c|}
\hline \multirow{2}{*}{$\begin{array}{c}\text { Average } \\
\text { density, } \\
\mathrm{kg} / \mathrm{m}^{3}\end{array}$} & \multicolumn{6}{|c|}{ Consumption of the materials per $1 \mathrm{~m}^{3}$ of foam concrete, $\mathrm{kg}$} & \multirow{2}{*}{$\begin{array}{l}\text { Water } \\
\text { cement }\end{array}$} & \multirow{2}{*}{$\begin{array}{c}\text { Concrete } \\
\text { mix } \\
\text { flowability, } \\
\mathrm{cm}\end{array}$} \\
\hline & cement & sand & $\begin{array}{l}\text { water in } \\
\text { solution }\end{array}$ & $\begin{array}{c}\text { foam } \\
\text { admixture* }\end{array}$ & $\begin{array}{c}\text { foam } \\
\text { volume }\end{array}$ & $\begin{array}{l}\text { water } \\
\text { in } \\
\text { foam }\end{array}$ & & \\
\hline 400 & 160 & 160 & 67 & 2,64 & 820 & 68 & 0,84 & 32 \\
\hline 500 & 210 & 210 & 86 & 2,49 & 763 & 62 & 0,7 & 28 \\
\hline 600 & 260 & 259 & 104 & 2,33 & 712 & 58 & 0,62 & 24 \\
\hline
\end{tabular}

* protein-based foam admixture was used

Besides, the sandy and slag soils with particles $1,2 \mathrm{~mm}$ had been irrigated by $30 \%$ silica sol complex with $\mathrm{Ca}(\mathrm{II})$ ions several times up to a full saturation level and then in 1 week soils were tested for strength.

\section{Results and discussion}

For soils complex of silica sol and solutions contained $\mathrm{Ca}$ (II) ions was used as well. In the Tables 6 and 7 the results of silica sol complex effects on the articles are indicated and one can establish that strengthening of the system took place due to silica sol action. 
Table 6. The results of silica sol complex absorption.

\begin{tabular}{|c|c|c|c|c|c|c|}
\hline \multirow{2}{*}{$\begin{array}{c}\text { Concrete } \\
\text { grade }\end{array}$} & $\begin{array}{c}\text { Hardness, } \\
+\Delta \%\end{array}$ & $\begin{array}{c}\text { compressive } \\
\text { strength, }+\Delta\end{array}$ & $\begin{array}{c}\text { bending } \\
\text { strength, } \\
+\Delta\end{array}$ & $\begin{array}{c}\text { water } \\
\text { absorption, }- \\
\Delta\end{array}$ & $\begin{array}{c}\text { abrasion, - } \\
\Delta\end{array}$ & $\begin{array}{c}\text { freeze } \\
\text { resistance } \\
\text { cycle, }+\Delta\end{array}$ \\
\hline $\begin{array}{c}\text { B15, } \\
\text { B20, }\end{array}$ & $\approx 60$ & $\approx 40$ & $\approx 40$ & -70 & -35 & +90 \\
B25,B30 & & & & & & \\
\hline
\end{tabular}

Table 7. The improvement of foam concrete properties when silica sol complex absorption technology was applied.

\begin{tabular}{|c|c|c|c|c|}
\hline \multirow{2}{*}{$\begin{array}{l}\text { Density of } \\
\text { foam } \\
\text { concrete, } \\
\mathrm{kg} / \mathrm{m}^{3}\end{array}$} & \multicolumn{4}{|c|}{ Change of foam concrete properties, $\%$; after 28 days of hardening } \\
\hline & $\begin{array}{c}\text { compressive } \\
\text { strength, }+\Delta \%\end{array}$ & hardness, $+\Delta \%$ & $\begin{array}{l}\text { freeze resistance, } \\
\text { cycle },+\Delta \%\end{array}$ & $\begin{array}{c}\text { water } \\
\text { absorption, } \\
-\Delta \%\end{array}$ \\
\hline 400 & $\approx 25$ & $\approx 50$ & $\approx 30$ & $\approx 70$ \\
\hline 500 & $\approx 25$ & $\approx 50$ & $\approx 30$ & $\approx 70$ \\
\hline 600 & $\approx 25$ & $\approx 50$ & $\approx 30$ & $\approx 70$ \\
\hline
\end{tabular}

The experiment results have shown that hardness of heavy concrete and foam concrete surface was increased to $60 \%$. It is very important to pay attention to water absorption reduction which occurred during geoecochemical processes with silica sol complex use. In the experiments foam concrete was applied as the "stone sponge" for oil products. Therefore when the surface was treated by silica sol complex there was not any extraction of oil products from foam concrete. On the other hand, silica sol complex use preserved concrete from the environment impact. That is why these technologies are named "safe technologies" [6-12].

It is known that in construction earth mass must be strengthened for some aims. In the experiments the soils were irrigated by silica sol complex several times up to a full saturation level. After 1 week strength was tested and as a result the soil strengthening was more than $0,5 \mathrm{MPa}$. So, the effects of silica sol complex are an alternative to $\mathrm{Na}_{2} \mathrm{SiO}_{3}$ action but in comparison with the latter silica sol is the purest substance for lithosphere. It means that silica sol use technology is the best one for an application. It should be noted that if basic slag and silica sol complex are used a mineral material surface strength is increased in several times.

Thus, it is evident that silica sol properties influence on a surface hardness both in mineral materials and in soils. However, they can be improved by means of the solutions use, e.g. solutions containing $\mathrm{PO}_{4}{ }^{3-}$, in order to form phosphates of heavy metal ions in a stone. Such a reaction is more efficient for detoxication increase. In the proceedings [13-19] the details of these effects are described.

\section{Conclusions}

1. The technology of the surface properties improvement with application of silica sol complex was demonstrated, the level of such an enhancement having been about $60 \%$.

2. The technology of the soil strengthening by means of $30 \%$ silica sol complex used several times was suggested. The level of the soil strengthening was more than $0,5 \mathrm{MPa}$, it having depended on how many times silica sol was applied as well as the nature of the soils.

3. The level of the soil strengthening could be increased more than $50 \%$ when silica sol complex was used. 


\section{References}

1. L.B. Svatovskaya, A.A. Kabanov, M.M. Sychov, IOP Conference Series: Earth and Environmental Science 90 012010, $1755-1315$ (2017) DOI: 10.1088/17551315/90/1/012010

2. L.B. Svatovskaya, A.A. Kabanov, M.M. Sychov, IOP Conference Series: Earth and Environmental Science 90 012009, $1755-1315$ (2017) DOI: 10.1088/17551315/90/1/012009

3. L.B. Svatovskaya, A.A. Kabanov, M.M. Sychov, Procedia Engineering 189, 398-403 (2017) DOI:10.1016/j.proeng.2017.05.063

4. L.B. Svatovskaya, O.V. Urov, A.A. Kabanov, Procedia Engineering 189, 454-458 (2017) DOI: 10.1016/j.proeng.2017.05.073

5. L.B. Svatovskaya, M.V. Shershneva, M.M. Baidarashvili, N.I. Yakimova, A.V. Khitrov, Proc. of the Int. Conf. on Sustainable Waste Management and Recycling (Construction Demolition Waste, London, 2004)

6. L.B. Svatovskaya, A.S. Sakharova, M.M. Baidarashvilly, A.V. Petriaev, Proceedings of the 14th International Conference of International Association for Computer Methods and Recent Advances in Geomechanics, Kyoto (2014)

7. A.M. Sychova, L.B. Svatovskaya, S.V. Mjakin, I.V. Vasiljeva, Electron Beam Modification of Solids: Mechanisms, Common Features and Promising Applications (2009)

8. L.B. Svatovskaya, N.I. Yakimova, O.Y. Trunskaya, E.V. Rusanova, N.B. Krylova, Proceedings of the International Conference on Sustainable Waste Management and Recycling (Construction Demolition Waste, London, 2004)

9. A.M. Sychova, A. Solomahin, V. Kotovich, L.B. Svatovskaya, Y. Kamenev, E3S Web of Conferences 33, 02058 (2018) DOI: https://doi.org/10.1051/e3sconf/20183302058

10. N. Gusev, L.B. Svatovskaya, A. Kucherenko, E3S Web of Conferences 33, 02069 (2018) DOI: https://doi.org/10.1051/e3sconf/20183302069

11. A. Sychova, M. Sychov, E. Rusanova, Procedia Engineering 189, 681-687 (2017) DOI: 10.1016/j.proeng.2017.05.108

12. A. Sychova, A. Solomahin, A. Hitrov, Procedia Engineering 189, 688-694 (2017) DOI: 10.1016/j.proeng.2017.05.109

13. A. Kavetsky, G. Yakubova, M. Sychov, Q. Lin, G. Walter, D. Chan, S. Yousaf, H. Socarras, J. Abrefah, K. Bower, Nuclear Science and Engineering 159, 321-329 (2008)

14. A.G. Kavetsky, S.P. Meleshkov, M.M. Sychov CRC Press 1, 1-38 (2002)

15. M.M. Sychov, Semiconductors 40-9, 1016-1020 (2006)

16. V.V. Bakhmetyev, S.V. Mjakin, V.G. Korsakov, A.M. Abyzov, M.M. Sychov, Glass Physics and Chemistry 37-5, 549-554 (2011)

17. M.M. Sychov, K.A. Ogurtsov, V.T.Lebedev, Yu.V. Kulvelis, Gy. Török, A.E. Sokolov, V.A. Trunov, V.V. Bakhmetyev, A.A. Kotomin, S.A. Dushenok, A.S. Kozlov, Semiconductors 46-5, 696-700 (2012)

18. M.V. Gravit, V.I. Gumenjuk, M.M. Sychov, O. Nedyshkin, Procedia Engineering 117, $119-125(2015)$

19. S.V. Mjakin, T.S. Minakova, V.V. Bakhmetyev, M.M. Sychov, Russian Journal of Physical Chemistry 90-1, 240-245 (2017) 